\title{
INFLUENCE OF DIFFERENT ORIGINS ON PRODUCTIVE ABILITIES OF THE FIRST CALVING SIMMENTAL COWS
}

\author{
Nebojša Lalić ${ }^{1}$, Zvonko Spasić ${ }^{1}$, Božidar Milošević1, Milinko Milenković ${ }^{1}$, Nikola Stolić ${ }^{2}$ \\ ${ }^{1}$ University of Priština, Faculty of Agriculture, Kosovska Mitrovica, \\ Jelene Anžujske b.b., 38228 Zubin Potok, Serbia \\ ${ }^{2}$ Agricultural College, Prokuplje, Serbia \\ dr.lalicn@gmail.com
}

\begin{abstract}
The basic scientific goal of this investigation was to make a complex view and study of milking traits of two Simmental cow groups in the production conditions of Southern Serbia. A total of 498 Simmental first calving cows and mother cows were investigated. The first calving cows originally arrived from Germany and a comparison of productive abilities between mother cows and their daughters has been performed. Average duration of all lactations investigated was 349.72 days in generation of daughters and 342.31 days in the generation of mothers. Milk production per standard lactation of the cows grown up in our conditions averaged $4127.87 \mathrm{~kg}$ with $3.66 \%$ or $151,26 \mathrm{~kg}$ of milk fat, and in the group of imported cows these values were $3321.14 \mathrm{~kg}, 3.80 \%$ and $142,82 \mathrm{~kg}$ respectively. Differences were statistically high significant in all parameters under investigation. The obtained results disclose the problem of acclimatizing of heads from the mother generation and confirm that import of more expensive animals with better genetic potential is economically justified for the breeder only when he is able to provide the best breeding practice and quality voluminous fodder.
\end{abstract}

Key words: cattle; Simmental; milk yield; milk fat yield; 4\% FCM

\section{ВЛИЈАНИЕ НА РАЗЛИЧНОТО ПОТЕКЛО ВРЗ ПРОИЗВОДНИТЕ СПОСОБНОСТИ НА СИМЕНТАЛСКИТЕ КРАВИ ПРВОРОТКИ}

\begin{abstract}
Основната научна цел на ова испитување беше да се изврши комплексен преглед и проучување на молзните својства на две групи сименталски крави во производни услови во јужна Србија. Вкупно беа испитани 498 сименталски крави, и тоа крави прворотки и крави мајки. Кравите прворотки потекнуваа од Германија и беше извршено споредување на продуктивните способности на кравите мајки и на нивните ќерки. Просечното траење на сите испитани лактации изнесуваше 349,72 дена во генерацијата на ќерки и 342,31 дена во генерацијата на мајки. Просечната вредност на продукцијата на млеко при стандардна лактација на кравите одгледани во наши услови изнесуваше $4127,87 \mathrm{~kg}$ со $3,66 \%$ односно $151,26 \mathrm{~kg}$ млечна маст, и во групата на увезени крави овие вредности беа $3321,14 \mathrm{~kg}, 3,80 \%$ и $142,82 \mathrm{~kg}$. Разликите беа статистички високо значајни кај сите испитани параметри. Добиените резултати го расветлуваат проблемот на аклиматизација на грлата од мајчината генерација и потврдуваат дека увозот на поскапи животни со подобар генетски потенцијал е економски оправдан за одгледувачот само кога е во можност да обезбеди најдобра одгледувачка пракса и квалитетна волуминозна кабаста храна.
\end{abstract}

Клучни зборови: говеда; симентал; продукција на млеко; количина на млечна маст; 4\% FCM

\section{INTRODUCTION}

Nowadays, the import of breeding cattle has increased in Serbia, especially import of the first calving Simmentall cows. Breeders are trying to improve the quality of their herds and increase the milk production. However, often there are no so high benefits from imported animals since high genetic potential can be expressed only if adequate measures such as good housing conditions, feeding 
regime and selection are introduced. Milk production is the basic goal of production and the most important source of income for the breeder. Thus, some investigators conduct experiments in order to compare production abilities of imported mother cows and their daughters in order to draw right conclusions regarding the quality and arrange their production technology according to the results obtained. The basic goal of our investigation was to compare milking abilities of daughters and their mothers that have been imported from Germany.

\section{MATERIAL AND METHODS}

A total of 498 Simmental first calving cows and mother cows were subject of our investigation. Conditions and housing were similar for both groups with the same feeding regime and feedstuffs quality. The information of the cows milk production was collected and incorporated into a database created in Microsoft Access for Windows software and then processed using the software Statistics for windows. Statistical difference has been determined using the $T$ test.

The following traits were the subject of investigation:

- duration of lactation (days) (DL),

- milk yield in standard lactation (kg) (MY),

- milk fat content in standard lactation (\%) (MFC),

- milk fat yield in standard lactation $(\mathrm{kg})$ (MFY),

Table 1
- yield of 4\% FCM in standard lactation $(\mathrm{kg})$ $4 \%$ (MKM),

\section{RESULTS AND DISCUSSION}

The first calving cows, that were the subject of our investigation, expressed high differences regarding milk production abilities (Table 1). High statistical differences $(\mathrm{P}<0.001)$ have been recorded in all investigated traits, except those showing duration of the lactation and milk fat content. Daughters, produced in our condition, had lactation that lasted 349.72 days, more for approximately 7 days, with no statistical differences. The milk production per standard lactation of the cows grown up in our conditions averaged $4127.8 \mathrm{~kg}$ with $3.66 \%$ or $151.1 \mathrm{~kg}$ of milk fat, and in the group of imported cows these values were 3321.14 $\mathrm{kg}, 3.8 \%$ and $125.96 \mathrm{~kg}$ of milk fat respectively.

The yield of $4 \%$ fat corrected milk in standard lactation averaged $3920 \mathrm{~kg}$ in daughters and in mothers it was $3210 \mathrm{~kg}$. No statistically significant differences were found in the fat content in milk between daughters and their mothers, imported the first calving cows of the Simmental breed. In the daughters' group $3.66 \%$ and in the group of mothers $3.80 \%$ of milk fat content has been recorded.

It could be concluded that the problem of acclimatization of heads influenced the milking abilities of imported first calving cows of the Simmental breed.

Milk production of the first calving cows and their mothers of the Simmental breed

\begin{tabular}{llll}
\hline \hline Traits & Mothers & Daughters & Significance \\
\hline Duration of lactation (days) & $342.31 \pm 68.90$ & $349.72 \pm 70.96$ & $\mathrm{P}=0.2377 \mathrm{~ns}$ \\
Milk yield & $3763.24 \pm 1235.08$ & $4777.04 \pm 1228.23$ & $\mathrm{P}<0.001^{* * *}$ \\
Milk yield in standard lactation & $3321.14 \pm 946.61$ & $4127.87 \pm 703.77$ & $\mathrm{P}<0.001^{* * *}$ \\
Milk fat yield & $142.82 \pm 46.15$ & $175.02 \pm 44.46$ & $\mathrm{P}<0.001^{* * *}$ \\
Milk fat yield in standard lactation & $125.96 \pm 34.63$ & $151.26 \pm 25.67$ & $\mathrm{P}<0.001^{* * *}$ \\
Milk fat content & $3.80 \pm 0.20$ & $3.66 \pm 0.19$ & $\mathrm{P}=0.2099 \mathrm{~ns}$ \\
Yield of 4\% FCM in standard lactation $(\mathrm{kg})$ & $3210.23 \pm 900.77$ & $3920.01 \pm 655.20$ & $\mathrm{P}<0.001^{* * *}$ \\
\hline \hline
\end{tabular}


Problems such as mastitis and inadequate forage quality caused a drop in production, comparing it with the production of the first calving Simmental cows in countries they were imported from. The milk production of the investigated first calving cows was actually much lower than the milk production in the standard lactation of Simmental first calving cows in Austria, which amounted more than $5000 \mathrm{~kg}$ (ZAR, 2000; Raganitsch, 2001).

Other authors have reported the acclimatization problem of imported cows in both the Simmental and the Black\&White breed in our production conditions too (Spasić, 1996, 1999). Better results were determined in the generation of daughters, produced in our conditions, in the first lactation. Both, productive and reproductive traits were worse in the imported group of cows, but later their production potential, after an adaptation to the housing and breeding conditions, they expressed better results and finally, in some cases, exceeded their daughters. Our conclusion that before an import of animals, necessary housing, feeding and other conditions must be provided can be supported by the results of investigation in Slovenia (Janžeković et al., 2004). In conditions where there are similar breeding cultures, differences between imported and domestic Simmental first calving cows were not recorded. Simply, in our conditions adaptation of animals lasts longer due to improper management. Our preliminary results are in accordance with previously mentioned conclusions given by Spasić that after a period, genetic potential of imported animals can be fully expressed. This genetic potential is undoubtedly very valuable and at the end incorporates a new quality in domestic population, which justifies the import process (Medić et al., 2006).

\section{CONCLUSIONS}

The obtained results highlight the problem of acclimatization of cattle imported from other areas. Results confirm that import of more expensive animals with better genetic potential is economically justified for the breeder during the first lactation only when he is able to provide the best breeding practice and quality voluminous fodder. Overall, imports of animals is necessary, since later productivity provides better income for farmers and, in turn, gives the possibility for better selection and improvement of the potential of domestic Simmental population.

\section{REFERENCES}

[1] Janžeković M., Skorjanc D., Smolinger J. (2004): The influence of various origins of first calving Simmental and Black-White cows on production and content of milk. Mljekarstvo, 54 (4) 275-283

[2] Medić D., Veselinović S., Veselinović Snežana, Ivančev Anica, Čupić Z. (2006): Uporedna ispitivanja osobina mlečnosti simentalskih krava domače i austrijske provenijence. Simpozijum stočarstvo $i$ agroekonomija u tranzicionim procesima. Herceg Novi.

[3] Raganitch G. (2001.): Das Österreichische Flekvieh und seine Genetik. 368 str.

[4] Spasić Z (1996): Varijabilnost i povezanost osobina mlečnosti $i$ plodnosti tri generacije domaćih šarenih goveda. Magistarska teza. Poljoprivredni fakultet. Beograd-Zemun.

[5] Spasić Z. (2000): Kvantitativno genetska analiza proizvodnih i reproduktivnih osobina krava u populaciji crno belih goveda. Doktorska disertacija. Poljoprivredni fakultet, Kruševac.

[6] Zentrale arbeitsgemeinschaft österreichischer Rinderzüchter - ZAR (2000.): Die österreichhische Rinderzuht Ausgabe, 2000, 26-80. 